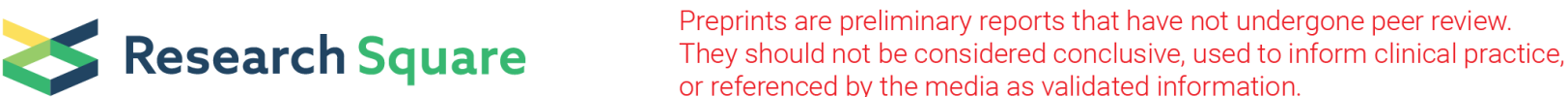

\section{The First Data on the Fauna and Geographical Distribution of Medically Important Scorpions in Golestan Province, Northeast of Iran}

\section{Aioub Sofizadeh}

Golestan University of Medical Sciences and Health Services

\section{Ehsan Allah Kalteh}

Golestan University of Medical Sciences and Health Services

\section{Shahin Saeedi}

Golestan University of Medical Sciences and Health Services

Mulood Mohammmadi Bavani ( $\nabla$ mulud.muhammady@yahoo.com )

Department of Medical Entomology and Vector Control, School of Public Health, Urmia University of Medical Sciences

\section{Research note}

Keywords: Scorpion, fauna, spatial distribution, Iran, Golestan

Posted Date: December 3rd, 2020

DOI: https://doi.org/10.21203/rs.3.rs-117232/v1

License: (c) (i) This work is licensed under a Creative Commons Attribution 4.0 International License. Read Full License 


\section{Abstract}

Objectives: this study was conducted to determine the medically relevant scorpion's species and produce their geographical distribution in Golestan Province for the first time, to collect basic information to produce regional antivenom. Because for scorpion treatment a polyvalent antivenom is use in Iran, and some time it failed to treatment, for solve this problem govement decide to produce regional antivenom.

Scorpions were captured at day and night time using ruck rolling and Ultra Violet methods during 2019. Then specimens transferred to a $75 \%$ alcohol-containing plastic bottle. Finally the specimens under a stereomicroscope using a valid identification key were identified. Distribution maps were introduced using GIS 10.4.

Results: A total of 111 scorpion samples were captured from the province, all belonging to the Buthidae family, including Mesobuthus eupeus (97.3\%), Orthochirus farzanpayi (0.9\%) and Mesobuthus caucasicus $(1.8 \%)$ species. M. eupeus has the highest distribution and abundance in the region and is introduced as the leading cause of scorpion sting in the region. This species was captured from allmountainous, forest and lowland areas. O. farzanpayi and M. caucasicus species are new for the scorpion fauna of golestan province.

Mesobuthus eupeus is the most prevalence species in Golestan province and regarded as the most medically important scorpion species in this region.

\section{Introduction}

Scorpions belong to one of the most orders of arachnids and are medically important arthropods. More than 2000 species have been identified so far. [1]

Currently, Iranian scorpion's fauna includes 66 species in three families: Buthidae (55 species and $86 \%$ of total species), Hemiscorpiidae (6 species and $9.5 \%$ of total species) and Scorpionidae (3 species $4.5 \%$ of total species). Scorpions are also venomous animals that annually between 40,000 to 50,000 persons are bitten by them in Iran and some cases lead to death. [1-5]

The reports of scorpion sting since ancient Iran are seen in religious and historical texts, indicating the history and importance of this issue in Iran. The problem of scorpion sting has always been presented in Iran. [6]

In recent years, many studies have been conducted on fauna, spatial distribution, morphological properties, ecological conditions, genetic diversity and their medical importance in Iran: According to these studies among 66 species of scorpion in Iran following species are medically relevant: Hemiscorpius lepturus and Hemiscorpius acanthocercus from Hemiscorpiidae and species of M. eupeus, Mesobuthus phillipsii, M. caucasicus, Androctonus crassicauda, Odontobuthus doriae, Odontobuthus bidentatus, Orthochirus iranus, Compsobuthus matthiesseni, Buthacus macrocentrus, O. farzanpayi, 
Apistobuthus susanae, Hottentotta saulcyi, Hottentotta zagrosensis and Hottentotta jaiakari from family Buthidae. As well as the following species: Hemiscorpius kashkayi \& Hemiscorpius shahi, Anomalobuthus talebii, Odontobuthus tirgari, Hottentotta navidpouri \& Hottentotta sistanensis and Orthochirus gantenbeini were added to the scorpion fauna of Iran recently. Mesobuthus eupeus phillipsii subspecies was raised to Mesobuthus phillipsii species. Among the mentioned species, the highest mortality due to scorpion sting in Iran is related to Hemiscorpius lepturus and Androctonus crassicauda, the first species causes mortality in the southern regions. However, the second species is distributed in many provinces of Iran. Also, M. eupeus has the highest distribution in Iran. [6-29] In Iran for the treatment of scorpion sting, a polyvalent antivenom is produced against venom of the species of $M$. eupeus, A. crassicauda, O. doriae, H. saulcyi, H. zagrosensis and H. lepturus. $[2,3,6]$ However, in recent years the number of scorpions in Iran has been increased. $[12,13,16]$. Razi Institute intends to produce monovalent or regional antivenom, and for this purpose, determining the fauna and geographical distribution of scorpions in all provinces of Iran is essential.

Regarding the high rate of scorpion sting and related mortality in the southern parts of the country, most studies have been conducted on scorpions in this region. But in other parts of Iran including Golestan province scorpion related studies have been neglected. There is a big gap in information in this field in Golestan province. So for the first time we conducted a study to determine the fauna and geographical dispersion map of collected species in this region of Iran.

\section{Materials And Methods}

Scorpions were collected from different localities of Golestan province using Rock Turing (in this methods we searched in different localities and habitats with different climates in urban and rural area including under stones and bark, on the farm and plow, near houses, in cemetery, dilapidated homes and grasslands) and Ultra Violet methods during 2019.

Geographical coordinates (Longitude, Latitude, and Altitude) of scorpion collection sites were recorded by GPS. The samples were transferred to a plastic bottle containing $70 \%$ ethanol alcohol. Morphological identification such as dentition of the pedipalp chela on movable finger, accessory granules under the terminal denticle on the pedipalp chela movable finger, rows of denticles on the pedipalp chela movable finger, pectinal teeth, carination, Trichobothria formula, were observed under stereomicroscope using standard Iranian scorpion identification keys and specimens were identified using a valid Iranian scorpion identification key. Distribution maps were introduced using GIS 10.4.

\section{Results}

Totally 111 specimens were captured from ten locations and four counties (Kalaleh, Maraveh Tapeh, Gonbad Kavous and Gorgan) from Golestan Province. Sixty females and 51 males' samples were identified. The sex ratio was 1: 0.85 in favor of females. All the scorpions collected belonged to Buthidae family, non-digging and included three species of $M$. eupeus, M. caucasicus and $O$. farzanpayi. 
This non-digging species had the highest frequency (108 samples) (97.3\%) comprising (50\%) 59 female and (50\%) 59 male with a sex ratio of 1: 1 . This species has a wide distribution in the province so that it was collected from all four studied counties (Kalaleh, Maraveh Tapeh, Gonbad-e Kavus, and Gorgan), as well as from all studied areas including mountainous and forest, mountainous and semi-arid and plain and semi-arid, which included both high and low altitude areas (Table 1 and Figs. 2 and 3).

Table 1

Species composition in different localities

\begin{tabular}{|c|c|c|c|c|c|c|c|}
\hline \multirow[t]{2}{*}{ Counties } & \multirow[t]{2}{*}{$\begin{array}{l}\text { Collection } \\
\text { sites }\end{array}$} & \multirow[t]{2}{*}{ altitude } & \multirow{2}{*}{$\begin{array}{l}\text { The geographical } \\
\text { and climatic } \\
\text { situation }\end{array}$} & \multirow[t]{2}{*}{ Species } & \multicolumn{3}{|c|}{$\begin{array}{l}\text { No. of the collected } \\
\text { sample }\end{array}$} \\
\hline & & & & & Female & Male & Total \\
\hline \multirow[t]{5}{*}{ Kalaleh } & Azizabad & 356 & $\begin{array}{l}\text { Mountainous and } \\
\text { forest }\end{array}$ & $\begin{array}{l}\text { Mesobuthus } \\
\text { eupeus }\end{array}$ & 0 & 1 & 1 \\
\hline & Pishkamar & 236 & $\begin{array}{l}\text { Mountainous and } \\
\text { semi-arid }\end{array}$ & $\begin{array}{l}\text { Mesobuthus } \\
\text { eupeus }\end{array}$ & 5 & 5 & 10 \\
\hline & Ooqchi & 331 & $\begin{array}{l}\text { Mountainous and } \\
\text { semi-arid }\end{array}$ & $\begin{array}{l}\text { Mesobuthus } \\
\text { eupeus }\end{array}$ & 2 & 2 & 4 \\
\hline & Khalednabi & 550 & $\begin{array}{l}\text { Mountainous and } \\
\text { semi-arid }\end{array}$ & $\begin{array}{l}\text { Mesobuthus } \\
\text { eupeus }\end{array}$ & 36 & 21 & 57 \\
\hline & & & & $\begin{array}{l}\text { Orthochirus } \\
\text { farzanpay }\end{array}$ & 1 & 0 & 1 \\
\hline \multirow[t]{3}{*}{$\begin{array}{l}\text { Maraveh } \\
\text { Tapeh }\end{array}$} & Coeilar & 1031 & $\begin{array}{l}\text { Mountainous and } \\
\text { forest }\end{array}$ & $\begin{array}{l}\text { Mesobuthus } \\
\text { eupeus }\end{array}$ & 1 & 5 & 6 \\
\hline & $\begin{array}{l}\text { Eslam } \\
\text { abad }\end{array}$ & 811 & $\begin{array}{l}\text { Mountainous and } \\
\text { semi-arid }\end{array}$ & $\begin{array}{l}\text { Mesobuthus } \\
\text { eupeus }\end{array}$ & 1 & 2 & 3 \\
\hline & Chaeili & 141 & $\begin{array}{l}\text { Plateau and semi- } \\
\text { arid }\end{array}$ & $\begin{array}{l}\text { Mesobuthus } \\
\text { eupeus }\end{array}$ & 4 & 6 & 10 \\
\hline \multirow[t]{3}{*}{$\begin{array}{l}\text { Gonbad- } \\
\text { e Kavus }\end{array}$} & Damaq & 58 & $\begin{array}{l}\text { Plateau and semi- } \\
\text { arid }\end{array}$ & $\begin{array}{l}\text { Mesobuthus } \\
\text { eupeus }\end{array}$ & 5 & 2 & 7 \\
\hline & $\begin{array}{l}\text { Dashli } \\
\text { Boron }\end{array}$ & 18 & $\begin{array}{l}\text { Plateau and semi- } \\
\text { arid }\end{array}$ & $\begin{array}{l}\text { Mesobuthus } \\
\text { caucasicus }\end{array}$ & 0 & 1 & 1 \\
\hline & & & & $\begin{array}{l}\text { Orthochirus } \\
\text { farzanpay }\end{array}$ & 0 & 1 & 1 \\
\hline Gorgan & Hezarpich & 427 & $\begin{array}{l}\text { Mountainous and } \\
\text { forest }\end{array}$ & $\begin{array}{l}\text { Mesobuthus } \\
\text { eupeus }\end{array}$ & 5 & 5 & 10 \\
\hline Total & & & & & 60 & 51 & 111 \\
\hline
\end{tabular}


This species has a large habitat, mostly caught beneath the cliffs of mountainous areas, beneath rocks in the plains, beneath footsteps of old buildings, beneath patches of brick and cement left in the backyard of rural homes, inside the abundant arthropods and rodents holes.

This species of scorpion in Iran is known as Iranian yellow scorpion, its color varies from yellow to orange with dark spots on carapace and abdomen and about 5 to $6 \mathrm{~cm}$ long, with a wide distribution in most provinces of Iran. Because of its willingness to live close to the human settlements, it can live in various habitats including beneath rocks, beneath garbage and construction debris and tree shells. The venom of this species is neurotoxic and is seen in cases where the person bitten by this scorpion feels thirsty, dizzy and uneasy due to fear. No mortality has been reported so far, although there have been reports of mortality from this scorpion sting in Tunisia and Algeria. $[2,9,30]$

Mesobuthus caucasicus

Only one male $(0.9 \%)$ sample of this species was collected in Gonbad-e Kavus County (low land area with semiarid climate). (Table 1 and Figs. 2 and 3 ).

This species is also known as the yellow scorpion and has a yellow body, only the middle and lateral eyes are black. Its length is about 6 to $6.5 \mathrm{~cm}$. The clinical forms of venom of this species of scorpion are similar to the clinical forms of M. eupeus venom. [2,9]

Orthochirus farzanpayi

Only two samples (one male and one female) ( $1.8 \%$ of all samples) of this species were collected from Khalaleh and Gonbad-e Kavus Counties. This species was captured from mountainous and semi-arid regions as well as lowland and semiarid areas (Table 1 and Figs. 2 and 3 ).

This species is 2.5 to $4 \mathrm{~cm}$ long and is one of the smallest species in Iran. The color of its abdomen is from brown to light brown. In 2006, a case of mortality from the sting of this species (Orthochirus spp) was reported from Khuzestan Province. The sting of this species caused relatively severe pain at the bite site, which results in pain after itching symptoms that last about 10 to 15 hours. $(2,9)$

\section{Discussion}

Our results showed that there were three species of scorpions including M. eupeus, M. caucasicus and O.farzanpayi in Golestan Province, all belonging to Buthidae family and no species of Hemiscorpiidae and Scorpionidae families were found. M. eupeus species was also collected in previous studies from Golestan Province. [5] But M. caucasicus and O. farzanpayi species were collected for the first time in this province. M. caucasicus species has been reported from Sistan and Baluchestan, Isfahan, Markazi, North Khorasan, Tehran, Semnan, Yazd and West, and East Azarbaijan. Orthochirus farzanpayi species from Hormozgan, Khuzestan, Bushehr, Kerman, North Khorasan and South Khorasan Provinces [5] Therefore, it can be concluded that according to previous studies $O$. farzanpayi species were reported mainly from southern provinces of the country and from Northern provinces it has been reported only from Northern 
Khorasan Province. Some species as Androctonus crassicauda, Orthochirus scrobiculosus, Scorpio maurus townsendi and Hemiscorpius lepturus have been reported from Semnan Province which is located in the south of Golestan province, but in our study, we couldn't capture these scorpions [5].

In a study conducted in Ardebil, East Azerbaijan and West Azerbaijan Provinces, similar to our results, $97.1 \%$ of collected scorpions belonged to Buthidae family, no species of Hemiscorpiidae was captured. Like our results: $M$. eupeus species was the most abundant species in this study and comprised $80.16 \%$ of the total samples [8] In another study conducted in North Khorasan Province, similar to our results, all the collected species belonged to Buthidae family and $M$. eupeus species had the highest frequency (59.44\%) with the most spatial distribution area in this province. [10]

A review study in Iran showed that more than $83.5 \%$ of scorpion sting belonged to Buthidae family and M. eupeus species has the highest distribution in Iran [2]

Other studies also showed that $M$. eupeus species is widely distributed in most provinces of Iran and is seen under different climatic conditions ranging from warm and lowlands regions (Khuzestan, Gorgan, Bandar Abbas and Varamin Plains) to snow-covered highlands. This agreed with our results $[4,5,26]$.

All three species collected in our study are medically important and $M$. eupeus is one of the six most important species in Iran, which produces antivenom against its venom for the treatment of scorpion sting all over the country. In this study, M. eupeus species had the highest distribution and abundance, which is introduced as the most important medical species in Golestan Province. This species has multiple habitats and is highly compatible with geographical and climatic conditions so that we were able to capture this species from different climates including high altitude areas (1031 $\mathrm{m}$ above sea level), lowland areas (58 $\mathrm{m}$ ) and medium-altitude areas, as well as high, medium and low vegetation areas. All of the above shows that such species is highly compatible with climate conditions, and for this reason it is distributed throughout the geography of Iran.

The size, color and appearance of Mesobuthus eupeus species varies according to the local form but reaches a maximum of about $6 \mathrm{~cm}$. This species in Iran has four subspecies: Mesobuthus eupeus eupeus, Mesobuthus eupeus kermanensis, Mesobuthus eupeus philippovitschi and Mesobuthus eupeus thersites.

M. e. eupeus subspecies have been collected from different regions of Iran i. Also in our study all the collected specimens of $M$. eupeus identified as M.e.eupeus. In this subspecies there are three lateral anal lobes on the fifth metasomal segment, venom gland width less than the fifth metasomal segment width and dark spots in the dorsal surface of carapace and mesosoma are arranged in 3-5 distinct bands. [9, 30]

O. farzanpayi and M. caucasicus species with the second and third abundance and distribution respectively are reported for the first time in Golestan Province. 
O. farzanpayi species belongs to Orthochirus genus, which was previously named as Orthochirus scrobiculosus form A, B, C and D. [9] unfortunately, some researchers now use the same name. However, according to studies conducted recently, the numbers of species of this genus have been increased in Iran, and also the species names have been changed as follows: Orthochirus iranus, Orthochirus farzanpayi, Orthochirus stockwelli, Orthochirus varius, Orthochirus gruberi, Orthochirus zagrosensis, Orthochirus iranus, Orthochirus gantenbeini and Orthochirus carinatus. $[9,14]$ In this study, we captured only two samples of 0 . farzanpayi.

M. caucasicus species can be captured inside the village and on the roofs of old rural houses. [8]

Previously this species was called Olivierus caucasicus belonging to Olivierus genus, but now researchers believe this species belongs to Mesobuthus genus. $[9,31]$ In this study, we could capture only one specimen of this species.

\section{Conclusion}

All studies conducted in Iran, including the present study, support the wide distribution of Buthidae family members, including $M$. eupeus species. Therefore, the Iranian yellow scorpion species in Golestan Province plays an essential role in scorpion sting and health authorities in this province should pay more attention to biological properties and environmental conditions in the scorpion control plan. The study results are also useful for the production of regional or monovalent anti-venom for Razi Institute.

\section{Limitations}

Golestan province is a large province but we captured specimens from limited collection sites; ten localities from four Counties (Kalaleh, Maraveh Tapeh, Gonbad Kavous and Gorgan), a similar study in wide geographical area including all counties in this province can be more reliable and the results can be a more realistic estimate of the scorpion fauna of Golestan province.

\section{Declarations}

\section{Funding}

This research was funded by the Research Deputy, Golestan University of Medical Sciences (Project No. 970620117).

\section{Authors' Contribution}

Aioub Sofizadeh and Mulood Mohammadi Bavani were the project designers of the research and wrote the manuscript. Ehsan Allah Kalteh did GIS analysis. Shahin Saeedi participated in writing the manuscript. 
There is no conflict of interest

\section{Acknowledgments}

Thanks go out to the health staffs of Golestan province for their collaboration.

\section{Ethics approval and consent to participate}

Not applicable

\section{Consent for publication}

Not applicable.

\section{Competing interests}

The authors declare that they have no competing interests in relation to the Present study

\section{References}

1. Dehghani R, Rafinejad J, Fathi B, Shahi MP, Jazayeri M, Hashemi. A retrospective study on Scropionism in Iran (2002-2011). J Arthropod Borne Dis. 2017;11(2):194-203

2. Dehghani R, Charkhloo E, Seyyedi-Bidgoli N, Chimehi E, Ghavami-Ghameshlo M. A Review on Scorpionism in Iran. J Arthropod Borne Dis. 2018;12(4):325-33.

3. Dehghani R, Fathi B. Scorpion sting in Iran: a review. Toxicon 2012;60(5):919-33. [doi: 10.1016/j.toxicon.2012.06.002]

4. Dehghani R, Haghi FM, Mogaddam MY, Sedaghat M, Hajati H. Review study of scorpion classification in Iran. J Entomol Zool Stud. 2016;4(5):440-44.

5. Motevalli Haghi F, Dehghani R. A review of scorpions reported in Iran. J Mazandaran Univ Med Sci. 2017;27(151):213-6. [10.18869/mjiri.31.27.]

6. Dehghani R. Scorpions and Scorpion sting (Biology, Ecology and control of them). Kashan Uni Med Sci. Persian, with Latin index), 2006:160.

7. Aydın Yağmur E, Moradi M, Larti M, Lashkari S. First record of Androctonus robustus Kovař́k \& Ahmed, 2013 (Scorpiones: Buthidae) for Iran. Zool Middle East. 2016;62(4):370-72. [10.1080/09397140.2016.1250861]

8. Bavani MM, Rafinejad J, Hanafi-Bojd AA, Oshaghi MA, Navidpour S, Dabiri F, et al. Spatial distribution of medically important scorpions in North West of Iran. J Arthropod Borne Dis. 2017;11(3):371-384.

9. Farzanpay R. Knowing scorpions. Central University Publications: Tehran, No. 312, Biology 4, in Persian, withLatin index);1987. p.231.

10. Firoozfar F, Saghafipour A, Vatandoost H, Bavani MM, Taherpour M, Jesri N, et al. Faunistic Composition and Spatial Distribution of Scorpions in North Khorasan Province Northeast of Iran. J 
Arthropod Borne Dis. 2019; 13: 353-61.

11. Karataş A, Gharkheloo M. A new hemiscorpius Peters, 1861 (Scorpiones: Hemiscorpiidae) from southwestern Iran. Turk J Zool. 2013;37(1):15-23.

12. Kovař́k F, Aydin Yağmur E, Moradi M. Two new Hottentotta species from Iran, with a review of Hottentotta saulcyi (Scorpiones: Buthidae). Euscorpius. 2018;:1-14.

[10.18590/euscorpius.2018.vol2018.iss265.1]

13. Kovařík F, Navidpour S, Soleglad M. Hemiscorpius shahii sp. n. from Iran (Scorpiones: Hemiscorpiidae). Euscorpius;2017:1-9. [10.18590/euscorpius.2017.vol2017.iss249.1]

14. Kovařík F, Yağmur EA, Fet V, Hussen F. A review of Orthochirus from Turkey, Iraq, and Iran (Khoozestan, llam, and Lorestan Provinces), with descriptions of three new species (Scorpiones: Buthidae). Euscorpius. 2019:1-31. [10.18590/euscorpius.2019.vol2019.iss278.1]

15. Masihipour B, Navidpour SJ. Study of morphometrical values of Iranobuthus krali (Scorpiones: Buthidae) from Fars province, southern Iran. Arch Razi Inst. 2009;64(2):97-100.

16. Mirshamsi O, Azghadi S, Navidpour S, Aliabadian M, Kovařík FJZ. Odontobuthus tirgari sp. nov. (Scorpiones, Buthidae) from the eastern region of the Iranian Plateau. Zootaxa. 2013;3731:153-70. [10.11646/zootaxa.3731.1.7]

17. Mirshamsi O, Sari A, Elahi E, Hosseinie S. Phylogenetic relationships of Mesobuthus eupeus (CL Koch, 1839) inferred from COI sequences (Scorpiones: Buthidae).J Nat Hist. 2010;44(47-48):2851-72. [DOI:10.1080/00222933.2010.512400]

18. Mongiardino Koch N, Ceccarelli FS, Ojanguren-Affilastro AA, Ramírez MJJJoEB. Discrete and morphometric traits reveal contrasting patterns and processes in the macroevolutionary history of a clade of scorpions. J EvolBiol. 2017;30(4):814-25. [DOI:10.1111/jeb.13050]

19. Moradi M, Yağmur EA, Gharakhloo PM, Ahmadi F. Scorpion Fauna of Zanjan Province, Iran (Arachnida: Scorpiones). J Evol Biol. 2015;9(1):11-4.

20. Navidpour S. A review study on Hottentotta Birula, 1908,(Scorpionida: Buthidae) species collected from Iran. 2012. Arch Razi Inst. 2012; 67(2): 93-100.

21. Navidpour S, Kovařík F, Soleglad M, Fet V. Scorpions of Iran (Arachnida, Scorpiones). Part X. Alborz, Markazi and Tehran Provinces with a description of Orthochirus carinatus sp. n.(Buthidae). Euscorpius. 2019; 276:1-20. [DOI: 10.18590/euscorpius.2012.vol2012.iss139.1]

22. Navidpour S, Nayebzadeh HH, Soleglad ME, Fet V, Kovařík F, Kayedi M. Scorpions of Iran (Arachnida: Scorpiones). Part VI. Lorestan Province. Euscorpius. 2010;104:1-23.

[DOI:10.18590/euscorpius.2010.vol2010.iss104.2]

23. Navidpour S, Soleglad ME, Fet V, Kovařík FJE. Scorpions of Iran (Arachnida, Scorpiones). Part IX. Hormozgan province, with a description of Odontobuthus tavighiae sp. n.(Buthidae). Euscorpius. 2013; 170:1-29. [DOI:10.18590/euscorpius.2013.vol2013.iss170.1]

24. Navidpour S, Studies B. An annotated checklist of scorpions in south and southwestern parts of Iran. Int J Fauna Biol. 2015;2(3):9-15. 
25. Nejati J, Mozafari E, Saghafipour A, Kiyani M. Scorpion fauna and epidemiological aspects of scorpionism in southeastern Iran. Asian Pac J Trop Biomed. 2014; 217-21. [DOI:

10.12980/APJTB.4.2014C1323]

26. Sedaghat M, Salehi MA, Dehghani R. Mapping the distribution of some important scorpions collected in the past five decades in Iran. Ann Mil Health Sci Res .2012; 9(4): 285-96

27. Teruel R, Kovarík F, Navidpour S, Fet VJE. The first record of the genus Anomalobuthus Kraepelin, 1900 from Iran, with description of a new species (Scorpiones: Buthidae). Euscorpius. 2014;:1-10. [DOI:10.18590/euscorpius.2014.vol2014.iss192.1]

28. Vazirianzadeh B, Jalali A, Chrom M, Mohammady A, Vatandoost H, Panahi F. A comparative study of nesting sites and burrowing habits of two Iranian burrowing scorpions. $J$ Arthropod Borne Dis .2017;11(1):78-85.

29. Gholizadeh S, Lalehzari E, Bavani MM, Hosseini A, Khalkhali HR, Rafinejad JJ, et al. Bioecology and scorpion envenomation in Ramshir district, Khuzestan Province, southwestern Iran. Appl Entomol Zool. 2016;51(1):37-42. [DOI:10.1007/s13355-015-0367-2]

30. Mirshamsi O, Sari A, Elahi E, Hosseinie S. Mesobuthus eupeus (Scorpiones: Buthidae) from Iran: A polytypic species complex. Zootaxa. 2011;2929(1):1-21. [DOI:10.5281/zenodo.201193]

31. Fet V, Kovařík F, Gantenbein B, Kaiser RC, Stewart AK, Graham MR. Revision of the Mesobuthuscaucasicus complex from Central Asia, with descriptions of six new species (Scorpiones: Buthidae). Euscorpius. 2018; 255:1-77. [DOI:10.18590/euscorpius.2018.vol2018.iss255.1]

\section{Figure Note}

Figure 2 is not available with this version.

\section{Figures}




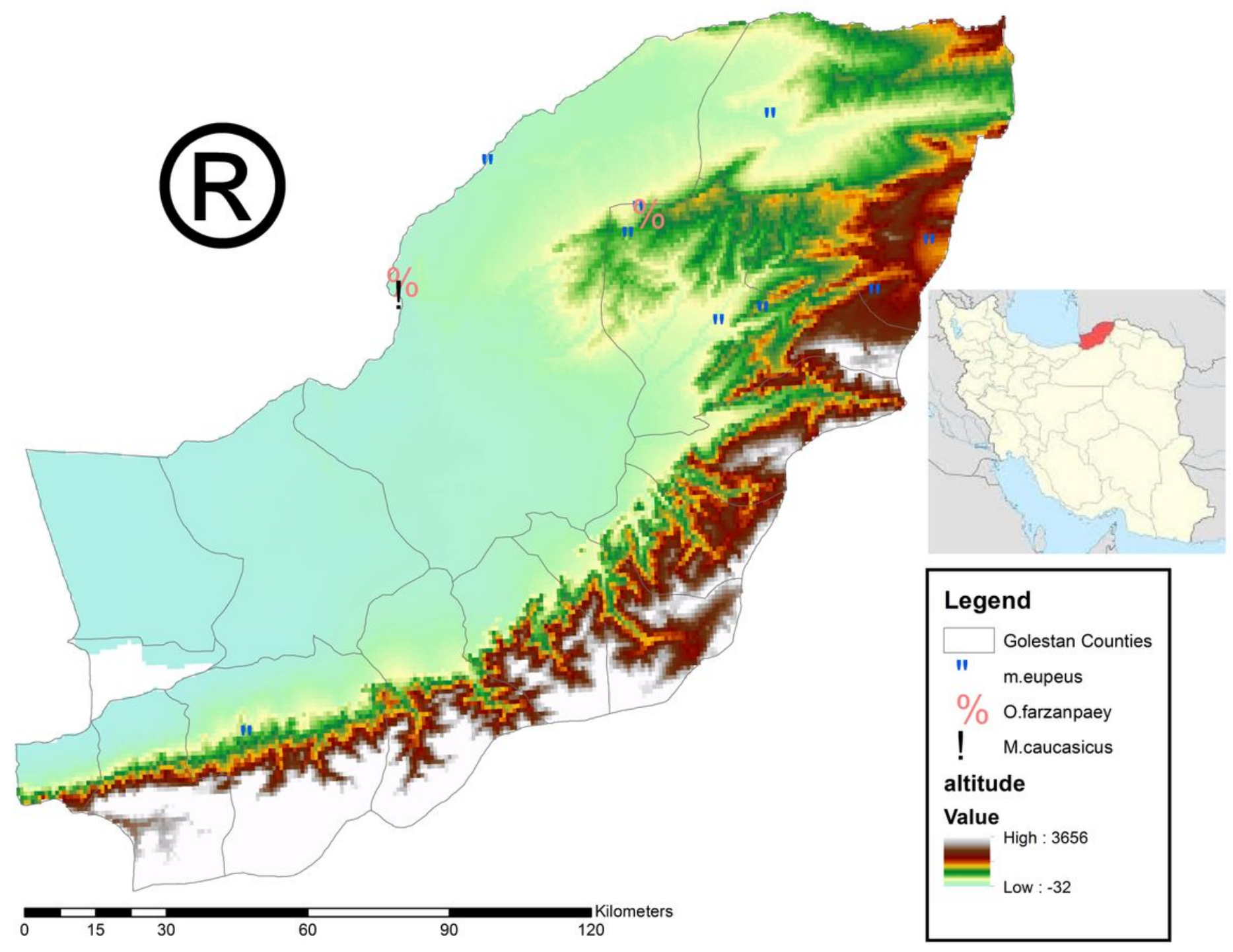

Figure 1

Spatial distribution of the collected species of scorpions in Golestan Province (based on altitude), 2019 Note: The designations employed and the presentation of the material on this map do not imply the expression of any opinion whatsoever on the part of Research Square concerning the legal status of any country, territory, city or area or of its authorities, or concerning the delimitation of its frontiers or boundaries. This map has been provided by the authors. 


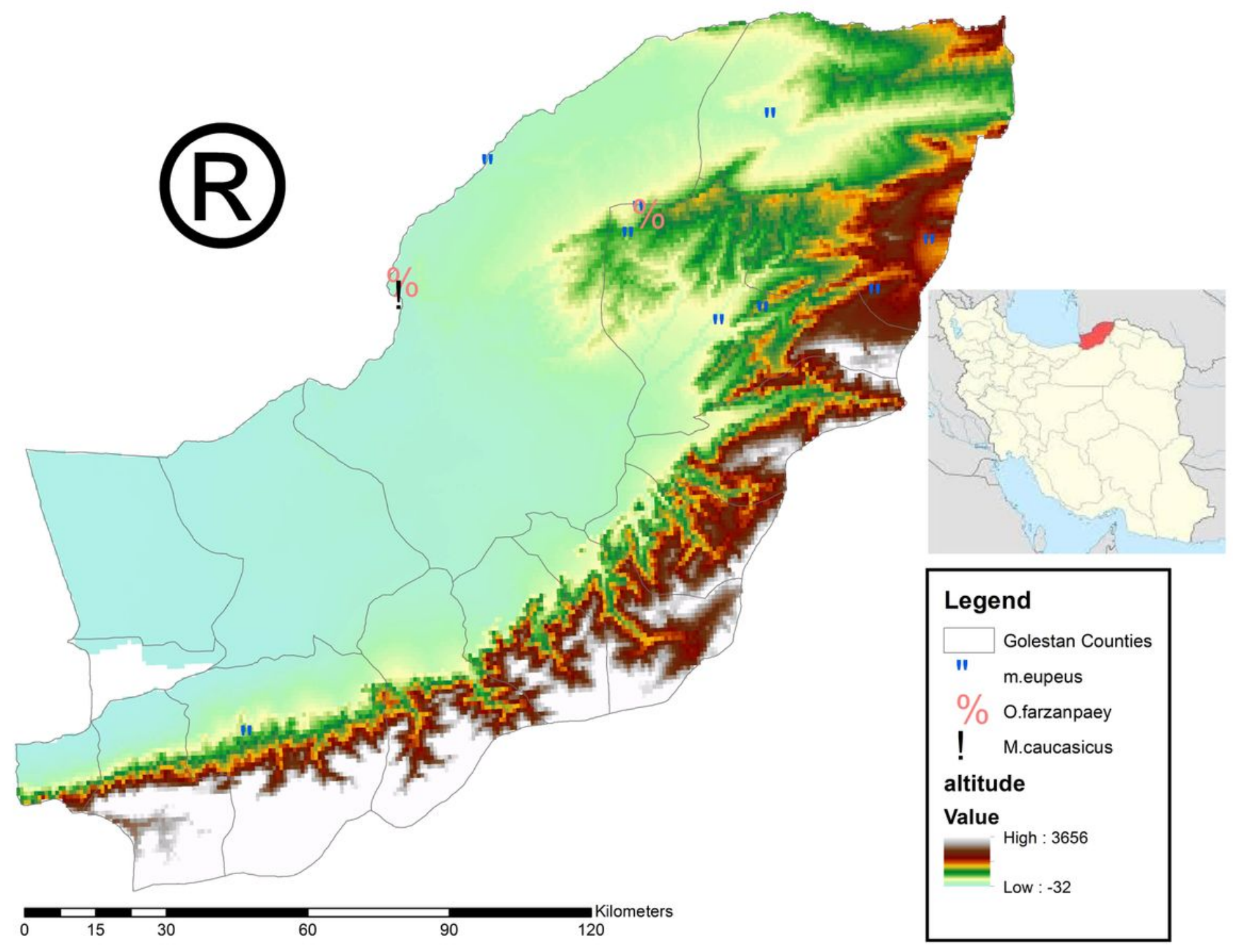

Figure 1

Spatial distribution of the collected species of scorpions in Golestan Province (based on altitude), 2019 Note: The designations employed and the presentation of the material on this map do not imply the expression of any opinion whatsoever on the part of Research Square concerning the legal status of any country, territory, city or area or of its authorities, or concerning the delimitation of its frontiers or boundaries. This map has been provided by the authors. 


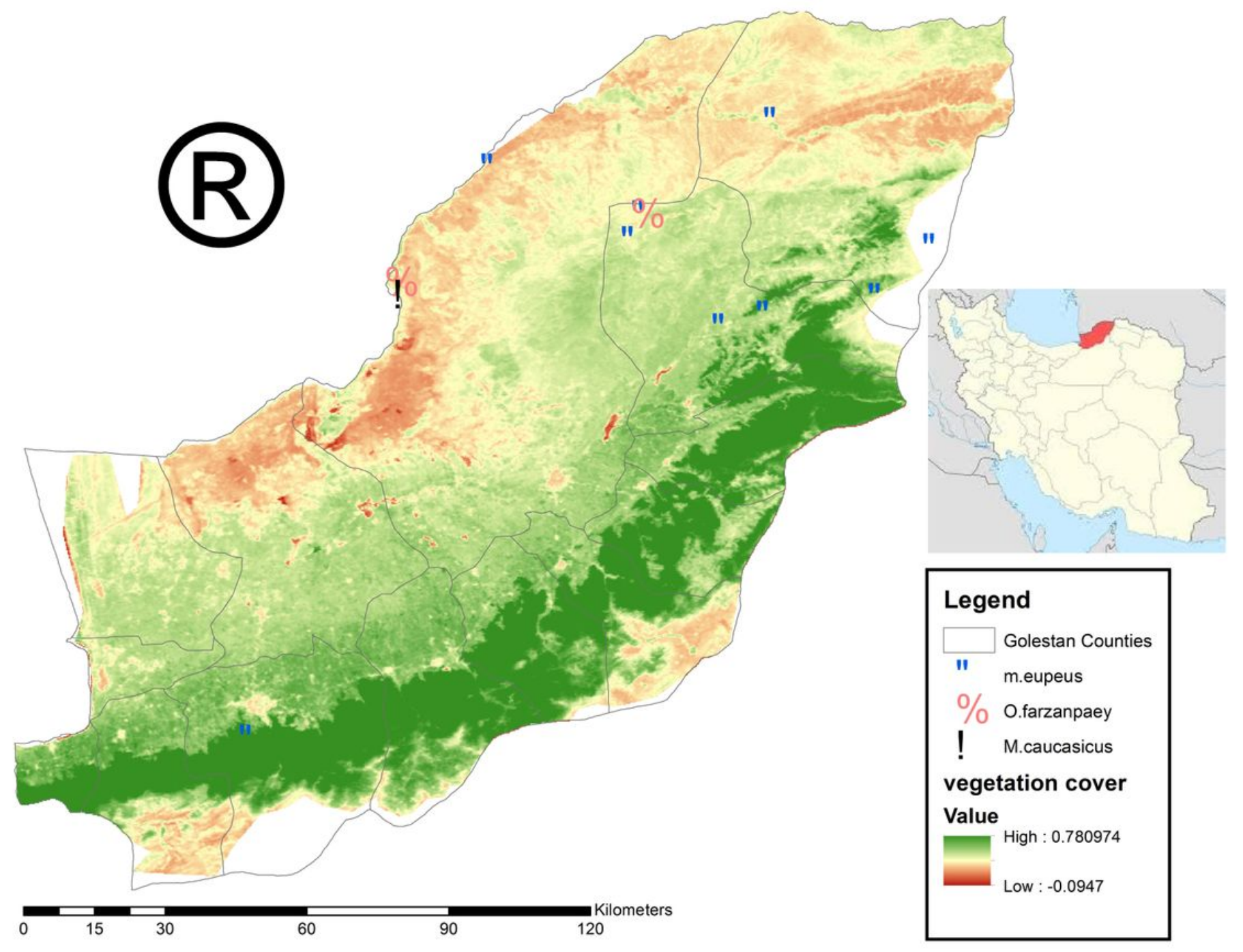

Figure 2

Spatial distribution of the collected species of scorpions in Golestan Province (based on vegetation cover), 2019 Note: The designations employed and the presentation of the material on this map do not imply the expression of any opinion whatsoever on the part of Research Square concerning the legal status of any country, territory, city or area or of its authorities, or concerning the delimitation of its frontiers or boundaries. This map has been provided by the authors. 


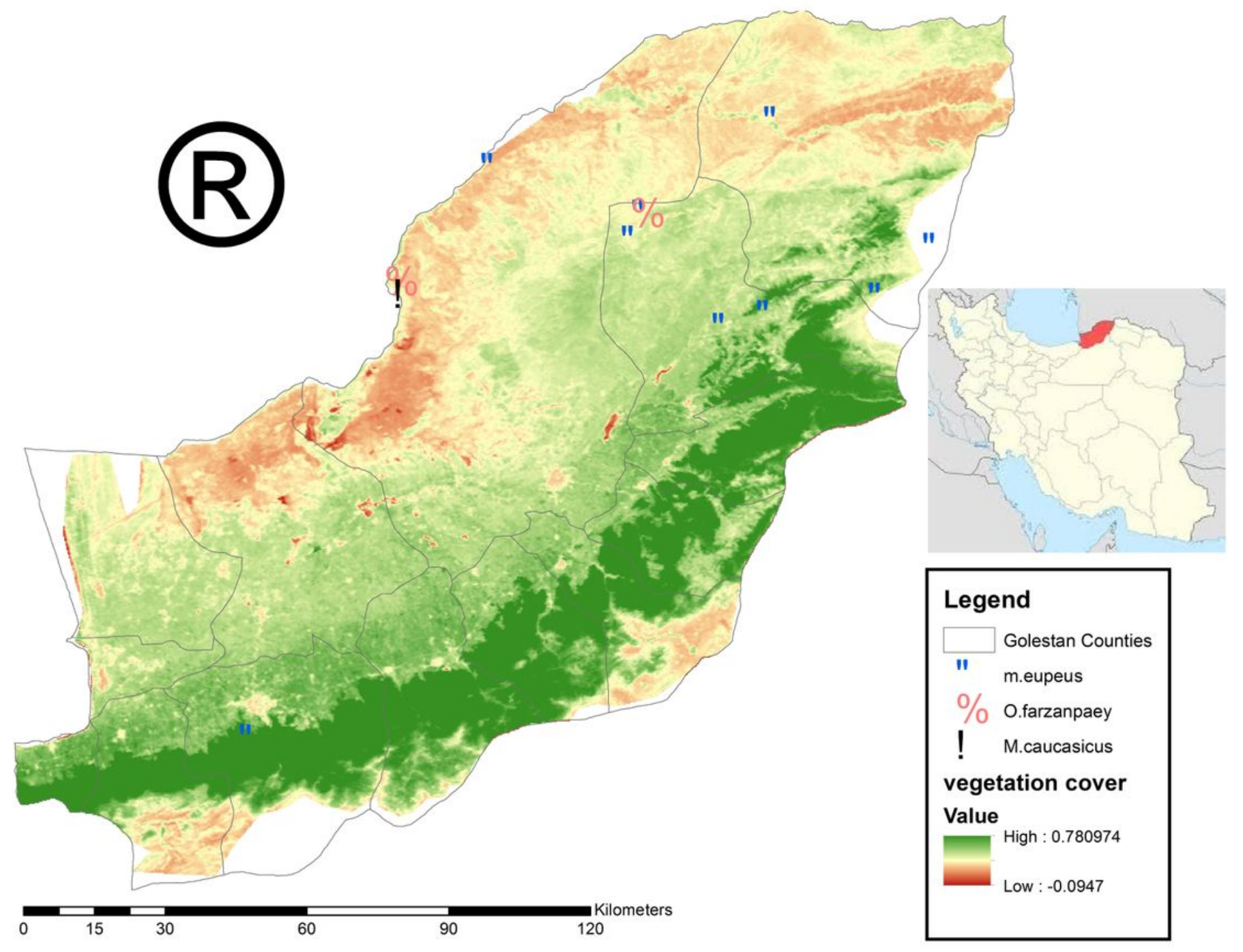

Figure 2

Spatial distribution of the collected species of scorpions in Golestan Province (based on vegetation cover), 2019 Note: The designations employed and the presentation of the material on this map do not imply the expression of any opinion whatsoever on the part of Research Square concerning the legal status of any country, territory, city or area or of its authorities, or concerning the delimitation of its frontiers or boundaries. This map has been provided by the authors. 